\title{
The most representative vertebrate fossil record and palaeontological heritage from the western Pyrenees
}

\author{
Ainara BADIOLA ${ }^{1 *}$, Mikel ARLEGI ${ }^{1,2}$, Humberto ASTIBIA ${ }^{1}$, Nathalie BARDET ${ }^{3}$, Ana \\ BERRETEAGA ${ }^{1}$, J. Carmelo CORRAL ${ }^{4}$, Ignacio DÍAZ-MARTÍNEZ ${ }^{5}$, Asier GÓMEZ- \\ OLIVENCIA ${ }^{1,6,7}$, Mikel A. LOPEZ-HORGUE ${ }^{1}$, Leire PERALES-GOGENOLA ${ }^{1} \&$ Xabier \\ PEREDA-SUBERBIOLA ${ }^{1 *}$
}

\footnotetext{
${ }^{1}$ Departamento de Estratigrafía y Paleontología, Facultad de Ciencia y Tecnología, Universidad del País Vasco/Euskal Herriko Unibertsitatea (UPV/EHU), Barrio Sarriena s/n, 48940 Leioa; ainara.badiola@ehu.eus, mikel.arlegui@ehu.eus, humberto. astibia@ehu.eus, asier.gomezo@ehu.eus,mikel.lopezhorgue@ehu.eus, leire.perales@ehu.eus, xabier.pereda@ehu.eus

${ }^{2}$ Université de Bordeaux, PACEA UMR 5199, Bâtiment B8, Allée Geoffroy Saint-Hilaire, 33615 Pessac, France.

${ }^{3}$ CR2P, UMR 7207 CNRS-MNHN-UPMC, Département Origines et Evolution, Muséum National d'Histoire naturelle, CP 38, 57 rue Cuvier, 75005 Paris, France ; nathalie.bardet@mnhn.fr

${ }^{4}$ Museo de Ciencias Naturales de Álava/Arabako Natur Zientzien Museoa, Siervas de Jesús 24, 01001 Vitoria-Gasteiz; jc.corral@arrakis.es

${ }^{5}$ CONICET - Instituto de Investigación en Paleobiología y Geología, Universidad Nacional de Río Negro, General Roca 1242, 8332 Fisque Menuco (General Roca), Río Negro, Argentina; inaportu@hotmail.com

${ }^{6}$ IKERBASQUE. Basque Foundation for Science, 48013 Bilbao

${ }^{7}$ Centro Mixto UCM-ISCIII de Evolución y Comportamiento Humanos. Avda. Monforte de Lemos, 5. 28029 Madrid

* Corresponding author
}

Badiola, A., Arlegi, M., Astibia, H., Bardet, N., Berreteaga, A., Corral, J.C., Díaz-Martínez, I., Gómez-Olivencia, A., LopezHorgue, M.A., Perales-Gogenola, L. \& Pereda-Suberbiola, X. 2019. The most representative vertebrate fossil record and palaeontological heritage from the western Pyrenees. [El registro fósil de vertebrados y patrimonio paleontológico más representativo de los Pirineos occidentales]. Spanish Journal of Palaeontology, 34 (1), 103-120.

\section{ABSTRACT}

The western Pyrenees is a territory with a remarkable geodiversity and an important fossil record, which constitutes a large archive of palaeobiodiversity. With respect to the vertebrate fossil record, the western Pyrenees (BasqueCantabrian Region, Pamplona Basin and the north-western sector of the Ebro Basin) are relevant both from the point of view of palaeontological sites and fossil collections. Several vertebrate fossil sites are integrated into the Inventory of Geological Interest Sites (LIG) with high to very high palaeontological interest of the Autonomous Community of the Basque Country. It is worth highlighting the Cretaceous

\section{RESUMEN}

Los Pirineos occidentales son un territorio con una notable diversidad geológica y un importante registro fósil, que constituye un gran archivo de paleobiodiversidad. En lo que respecta al registro fósil de vertebrados, los Pirineos occidentales (Región Vasco-Cantábrica, Cuenca de Pamplona y sector noroccidental de la Cuenca del Ebro) son relevantes tanto desde el punto de vista de los yacimientos paleontológicos como de las colecciones de fósiles procedentes de ellos. Varios yacimientos de vertebrados forman parte del Inventario de Lugares de Interés Geológico (LIG) con alto o muy alto interés paleontológico en la Comunidad Autónoma del 
fish sites of Zeanuri in Biscay, Eocene mammals of Zambrana and Miocene ichnites of Salinas de Añana in Araba, and the Pleistocene vertebrate fossil assemblage of Kiputz near Mutriku, in Gipuzkoa. Other highly significant sites in the study area should be subject to geoconservation initiatives. This is the case of the Laño quarry in the Condado de Treviño, which has provided continental and marine vertebrate fossil assemblages from the latest Cretaceous, Eocene to Early Miocene sites with bird and mammal tracks in Navarre, and the Pleistocene cave deposits of Santa Isabel de Ranero in Biscay, to mention only the most outstanding examples. There are also vertebrate fossil collections in the western Pyrenees that stand out for their high palaeontological interest, although some do not come from recognized LIG. These collections are deposited in several centres and institutions of Bilbao, Irun, Leioa, Pamplona-Iruñea and Vitoria-Gasteiz. The valuation of the palaeobiodiversity and fossil record is an important step for the study of palaeontological heritage of a territory and the set-up of geoconservation designations (e.g., LIG, geosites). However, the mere inclusion of the palaeontological assents in these geoconservation designations does not guarantee either their protection and conservation or the suitable management of the fossil collection. Therefore, it is necessary to design conservation strategies taking into account the particularities of each palaeontological site and/or fossil collection. The scientific and cultural dissemination of the palaeontological heritage of a territory like one studied here should have greater collaboration between the palaeontologists that have valued the palaeontological assets and the technicians and institutions that manage them. This requires the provision of specific budgetary items that enable the development of the different activities of research, conservation and social dissemination of this heritage.

Keywords: Fossil vertebrates, palaeontological sites and collections, Cretaceous-Cenozoic, western Pyrenees.

\section{INTRODUCTION}

The western Pyrenees is a territory of remarkable geodiversity, as it is a region where different geological domains converge: Pyrenean axial zone, north-Pyrenean and south-Pyrenean zones -including the BasqueCantabrian inverted basin- and the Aquitaine and Ebro foreland basins. Most of the geological formations are composed of sedimentary rocks, in some cases with extremely thick sequences. These characteristics explain its important fossil record, which represents a large archive of palaeobiodiversity. It corresponds to a time lapse that includes most of the Phanerozoic and a notable variety of palaeoecosystems, both marine and continental. In a previous work (Badiola et al., 2018a), we summarized the geology of the western Pyrenees and highlighted
País Vasco. Destacan los yacimientos de peces cretácicos de Zeanuri en Bizkaia, mamíferos eocenos de Zambrana e icnitas miocenas de Salinas de Añana en Álava/Araba y la asociación de vertebrados pleistocenos de Kiputz cerca de Mutriku, en Gipuzkoa. Otros yacimientos notables en el área de estudio deberían ser objeto de iniciativas de geoconservación: es el caso de la cantera de Laño (Condado de Treviño), con asociaciones finicretácicas de vertebrados continentales y marinos, los afloramientos con icnitas de aves y mamíferos del Eoceno al Mioceno inferior de Navarra/Nafarroa y la cueva vizcaína de Santa Isabel de Ranero (Pleistoceno), por citar únicamente los ejemplos más sobresalientes. Asimismo, existen colecciones de fósiles de vertebrados en los Pirineos occidentales que destacan por su elevado interés paleontológico, aunque algunos no provengan de LIG reconocidos. Estas colecciones están depositadas en diversos centros e instituciones de Bilbao, Irún, Leioa, Pamplona-Iruñea, y Vitoria-Gasteiz. La valoración de la paleobiodiversidad y el registro fósil es un paso importante para el conocimiento del patrimonio paleontológico de un territorio y la creación de figuras de geoconservación (e.g., LIG, geosites). Sin embargo, la mera inclusión de los yacimientos paleontológicos en estas figuras no garantiza su protección y conservación, ni la adecuada gestión de las colecciones de fósiles procedentes de ellos. Por lo tanto, es necesario diseñar estrategias de conservación transversales teniendo en cuenta las particularidades de cada yacimiento $\mathrm{y} / \mathrm{o}$ colección. La divulgación científica y cultural del patrimonio paleontológico de un territorio, como el aquí estudiado, debe contar con una mayor colaboración entre los paleontólogos que han valorado los bienes paleontológicos y los técnicos que los gestionan. Para ello, es necesaria la disposición de partidas presupuestarias específicas que posibiliten el desarrollo de diferentes acciones encaminadas a la investigación, conservación y difusión social de este patrimonio.

Palabras clave: Vertebrados fósiles, yacimientos y colecciones paleontológicas, Cretácico-Cenozoico, Pirineos occidentales. the large Phanerozoic palaeobiodiversity archive that exists in this area together with its high scientific and sociocultural values, these latter having been object of several geoconservation initiatives.

In this work, we focus on the vertebrate fossil record and palaeontological heritage (sites and collections) from the Basque-Cantabrian Region and adjacent areas (Pamplona Basin and the north-western sector of the Ebro Basin), including territories from the Autonomous Community of the Basque Country (CAPV), the Chartered Community of Navarre (CFN) and the north of the Community of Castile and León (CyL). The oldest vertebrate fossil remains are located in Paleozoic rocks of Navarre (i.e., conodonts from the Devonian and Carboniferous of Eugi surroundings and selachian teeth from the Devonian of Aldude-Kintoa) (Bodego et al., 2014), but the most 
important sites are known from the Mesozoic and the Cenozoic (Badiola et al., 2018a and references therein). This fossil record has provided information on different marine and terrestrial ecosystems and some important biotic changes that occurred during the last 145 million years in this area (Badiola et al., 2018a). Some of the vertebrate palaeontological sites were previously integrated into the Inventory of Geological Interest Sites (Mendia et al., 2013; LIG, acronym of Lugar de Interés Geológico) or the Geosites Inventory of Spain (see http://info.igme.es/ ielig/), whereas other sites are not yet included and should be subject to future geoconservation initiatives according to our criteria. Finally, we mention the vertebrate fossil collections with high to very high palaeontological interest, whether they are included or not in the Inventory of LIG, and the institution in which they are housed.

Abbreviations for repositories. AEA, Asociación Etnográfica Aztarna de Amurrio (Araba); AM, Arkeologi Museoa, Bilbao (Biscay); CIFL, Centro de Interpretación de las Foces de Lumbier/Irunberri (Navarre); FA, Fondos de Arqueología, Gobierno de Navarra, Pamplona-Iruñea (Navarre); Gordailua, Centro de Patrimonio Cultural Mueble Gordailua, Irun (Gipuzkoa); ICP, Institut Català de Paleontologia Miquel Crusafont de Sabadell (Barcelona); MCNA, Museo de Ciencias Naturales de Álava/Arabako Natur Zientzien Museoa, Vitoria-Gasteiz (Araba); UPV/EHU-EP, Universidad del País Vasco/Euskal Herriko Unibertsitatea, Departamento de Estratigrafía y Paleontología, Leioa (Biscay).

\section{PALAEONTOLOGICAL HERITAGE OF THE WESTERN PYRENEES}

In this section, the vertebrate palaeontological heritage from the Basque-Cantabrian Region and from the Pamplona and NW Ebro basins is presented. The palaeontological sites included in the LIG inventory and the fossil collections with high to very high palaeontological interest are summarized here (see also Tables 1 and 2). The only palaeontological sites recognized as LIG are those from the CAPV. We propose other sites valued as high or very high palaeontological interest in the CAPV and other territories (Navarre and Castile and León), as well as the fossil collections that should be subject to geoconservation strategies. The Table 3 shows the institutions where the fossil collections are reposited.

\subsection{Basque-Cantabrian region}

The approval of the "Geodiversity Strategy of the CAPV 2020 " in 2014 has allowed for the orderly management of geodiversity and geological heritage in the Autonomous
Community of Basque Country. The inventory work took into account 312 previous LIG, of which 150 were included within the LIG-CAPV Inventory (Mendia et al., 2013); 45 of the 150 correspond to high or very high palaeontological interest LIG (Gobierno Vasco, 2014; Monge-Ganuzas et al., 2018: p. 244, table 2). Five of them are directly related to vertebrate fossils. Chronostratigraphically, one site is of Cretaceous age, one is from the Eocene, one is from the Miocene, and two are from the Quaternary (Table 1). Other sites included in this inventory contain scarce but highly significant vertebrate fossils (see below).

\subsubsection{Vertebrate fossil sites with high to very high palaeontological interest included within the LIG-CAPV Inventory}

Zeanuri fish fossil site (LIG PV131). (Fig. 1, No. 1; Tables 1, 3). In the Arratia valley (Biscay), along the nucleus of the Bilbao Anticlinorium, several ValanginianBarremian fish-bearing beds are known. More specifically, three types of clupeomorphs have been identified in these outcrops. The Zeanuri outcrop is the most accessible and has provided to date the most complete collection of fish fossils from the Basque-Cantabrian Basin. The fossils are preserved in black shales representing deposits in a restricted freshwater-brackish coastal lagoon environment fed with deltaic siliciclastics that was occasionally affected by marine incursions. External moulds of complete articulated skeletons of teleostean fishes are observed. Based on several specimens, the new taxon Ezkutuberezi carmeni was erected by Poyato-Ariza et al. (2000) (Fig. 2a). It is the first European Cretaceous clupeomorph to be described in detail, and the first articulated vertebrate fossil to be described from the Basque-Cantabrian Basin. The fossils are preserved at the MCNA of Vitoria-Gasteiz and in the palaeontological collections of the UPV/EHU$\mathrm{EP}$ at Leioa. Other levels containing rich fossil fish assemblages are known from the localities of Artea and Areatza (Poyato-Ariza et al., 2000). They are detailed at the end of this section.

Zambrana mammal fossil site (LIG PV128). (Fig. 1, No. 2; Tables 1, 3). Zambrana (Araba) is a late Eocene (Priabonian) palaeontological site of special relevance in the Iberian and European contexts. The stratigraphic section ( $200 \mathrm{~m}$ in thickness) of the Zambrana outcrop corresponds to the first lacustrine system described in the southern flank of the Miranda-Treviño Syncline (Basque-Cantabrian Region) (Astibia et al., 2000), which together with the lacustrine limestones of the Loza Syncline (LIG PV51) (Fig. 1, No. 8), are to date the best Paleogene continental record in this area. Zambrana is one of the few examples of the pre-Quaternary vertebrate fossils assemblages preserved in a swampy circumlake environment and studied in a wide taphonomic 


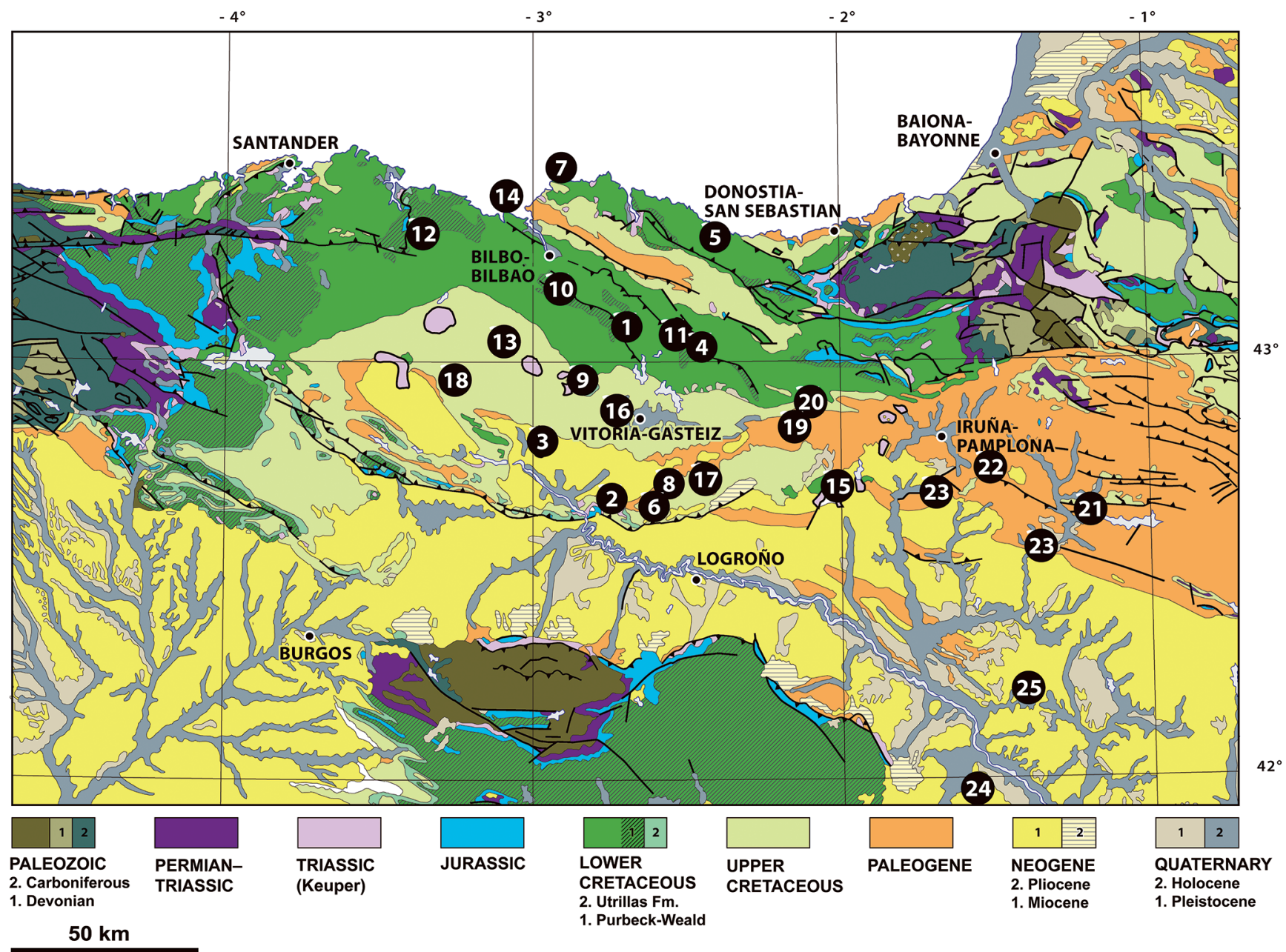

Figure 1. Geological location of the vertebrate fossil sites with high to very high palaeontological interest from the western Pyrenees (Basque-Cantabrian Region, Pamplona Basin and the north-western sector of the Ebro Basin). Palaeontological sites included within the LIG-CAPV Inventory: 1, Zeanuri fish fossil site (LIG PV131), Biscay; 2, Zambrana mammal fossil site (LIG PV128), Araba; 3, Salinas de Añana ichnosite (LIG PV130), Araba; 4, Arrikrutz Cave (LIGPV 165), Gipuzkoa; 5, Kiputz site (LIG PV95), Gipuzkoa; 6, Peñacerrada/Urizaharra amber sites (LIG PV129, also CV010; Geosites FC009 and FC010), Araba and Condado de Treviño; 7, Azkorriaga Fort site, Gorliz (LIG PV26), Biscay; 8, Lacustrine Limestones of the Loza syncline (LIG PV51), Araba; 9, Murgia palustrine fossil site (LIG PV137), Araba. Vertebrate fossil sites that should be added to the LIG-CAPV Inventory; 10, Villaro Formation in the Arratia valley, Biscay and Gipuzkoa; 11, Villaro Formation in the Deba valley, Gipuzkoa; 12, Santa Isabel de Ranero Cave, Karrantza, Biscay. Vertebrate fossil collections in the CAPV that should be subject to geoconservation initiatives; 13, Late Cretaceous beds of the Aiara valley, Araba; 14, Punta Lucero Quarry, Zierbena, Biscay. Vertebrate fossil sites and collections from the Basque-Cantabrian Region in Navarre and Castile and León that should be subject to geoconservation initiatives; 15, Zufia Formation, Estella-Lizarra, Navarre; 16, Gometxa and Vitoria Pass, Araba; 17, Laño Quarry, Condado de Treviño; 18, Quintanilla la Ojada Quarry, Burgos. Vertebrate fossil collections from the Basque-Cantabrian Region in Navarre that should be subject to geoconservation initiatives; 19, Urbasa-Andia Natural Park, Navarre; 20, Koskobilo Quarry, Olazti, Navarre. Vertebrate fossil sites from the Pamplona Basin that should be subject to geoconservation initiatives; 21, Pamplona Basin avian ichnosites, Navarre. Vertebrate fossil collections from the Pamplona Basin to be added to conservation strategies of the palaeontological heritage; 22, Sirenian sites from the Egües valley/Eguesibar, Navarre. Vertebrate fossil sites from the NW Ebro Basin that could be subject to geoconservation initiatives; 23, NW Ebro Basin mammal and bird ichnosites, mainly Oibar/Aibar and Olkotz, Navarre; 24, Monteagudo macromammal fossil site, Navarre; 25, Bardenas Reales fossil sites and ichnosites, Navarre. Abbreviations: CAPV, Comunidad Autónoma del País Vasco (Autonomous Community of Basque Country); LIG PV, Lugares de Interés Geológico del País Vasco (Geological Interest Sites from the Basque Country). Figure from J.C. Corral. Simplified map from the Mapa Geológico de la Península Ibérica, Baleares y Canarias, scale 1:1.000.000, IGME, Madrid, 2001. 
Table 1. Palaeontological sites with high or very high palaeontological interest from the western Pyrenees (Basque-Cantabrian Region) included within the LIG-CAPV Inventory. Sites containing scarce but highly significant vertebrate fossils are indicated by an asterisk. The sites are sorted from most recent to oldest. Abbreviations: CAPV, Comunidad Autónoma del País Vasco (Autonomous Community of Basque Country); CyL, Castilla y León (Castile and León).

\begin{tabular}{llllc}
\hline \multicolumn{1}{c}{$\mathbf{N}^{\mathbf{0}}$ LIG } & \multicolumn{1}{c}{ Geosite } & \multicolumn{1}{c}{ Vertebrate site } & \multicolumn{1}{c}{ Age } & Aut. Com. \\
\hline PV65 & & Arrikrutz Cave (Gipuzkoa) & Quaternary & CAPV \\
PV95 & & Kiputz site (Gipuzkoa) & Quaternary & CAVP \\
PV130 & & Salinas de Añana ichnosite (Alava/Araba) & early Miocene & CAPV \\
PV137 & & Murgia palustrine fossil site* (Alava/Araba) & early Miocene & CAPV \\
PV128 & & Zambrana mammal fossil site (Alava/Araba) & late Eocene & CAPV \\
PV51 & & Loza syncline* (Alava/Araba) & Eocene & CAPV \\
PV26 & & Azkorriaga Fort site*, Gorliz (Biscay) & Early Cretaceous & CAPV \\
PV129 & FC009 & Peñacerrada amber sites* (Araba and Condado de & Early Cretaceous & CAPV \\
PV131 & FC010 & Treviño) & Early Cretaceous & CAPV \\
\hline
\end{tabular}

Table 2. Vertebrate sites from the western Pyrenees with high to very high palaeontological interest that could be subject to geoconservation estrategies (see the text for more details).

\begin{tabular}{lll}
\hline \multicolumn{1}{c}{ Vertebrate site } & \multicolumn{1}{c}{ Age } & \multicolumn{1}{c}{ Main relevance } \\
\hline $\begin{array}{l}\text { Santa Isabel de Ranero (Biscay) } \\
\text { Xabier-Ledea sites (Navarre) } \\
\text { Quintanilla la Ojada Quarry (Burgos) }\end{array}$ & $\begin{array}{l}\text { Quaternary } \\
\text { late Eocene } \\
\text { Late Cretaceous }\end{array}$ & $\begin{array}{l}\text { Abundant fossils of Deninger's bears } \\
\text { Avian footprints (new ichnotaxon) } \\
\text { Rich continental and marine fossils (new } \\
\text { taxa) } \\
\text { Laño Quarry (Condado de Treviño) }\end{array}$ \\
$\begin{array}{ll}\text { Villaro Fm., Arratia and Deba Valleys, fish } \\
\text { fossils (Biscay and Gipuzkal and marine fossils (new } \\
\text { Estella-Lizarra fish fossils (Navarre) }\end{array}$ & Early Cretaceous & Exceptional preservation (new taxa) \\
\hline
\end{tabular}

context (Badiola et al., 2009a). The exceptionality of the Zambrana site is accentuated by the presence of unique mammal fossil assemblages corresponding to the MP 18 Mammal Paleogene reference level (Astibia et al., 2000). The fossiliferous strata consist of palustrine-lacustrine coal-bearing marls and marlstones. They have yielded fossils of seeds of an aquatic plant, charophytes (oogonia), invertebrates (ostracods and gastropods) and vertebrates. At least 26 different vertebrate taxa have been identified, including squamates, amphibians, turtles, crocodilians and mammals (Badiola, 2004). Mammals consist of a didelphid marsupial, a small nocturnal and frugivorous omomyform primate, four different therydomorph rodents and a possible remyoid rodent, two miacid carnivores, five artiodactyls (dichobunids, xiphodontids, and anoplotheres) and seven perissodactyls (Badiola et al., 2009b, 2018b), including the new equoid taxa Pachynolophus zambranensis and Iberolophus arabensis (Badiola et al., 2005; Badiola \& Cuesta, 2008) (Fig. 2d). Additionally, a manuscript describing another two new equoids is in preparation. The study of the mammal fossil association has provided interesting hypotheses of work to expand the European mammalian palaeoecology and palaeobiogeography
(Badiola et al., 2009b), before many of these disappeared during the biological crisis of the Eocene-Oligocene boundary. Fossils are reposited at the MCNA of VitoriaGasteiz and in the palaeontological collections of the UPV/ EHU-EP (Leioa) until their study is finished.

Salinas de Añana ichnosite (LIG PV130). (Fig. 1, No. 3; Tables 1, 3). The early Miocene (Aragonian, biozone MN 4 to 6) site of Salinas de Añana (Araba) contains exceptionally well-preserved vertebrate ichnites. An area of about 60 square meters has been excavated until now, yielding some 700 tracks and at least 15 individual trackways, which correspond to seven different ichnospecies: five assigned to mammals (three carnivores and two artiodactyls) and two to birds. The didactyl tracks have been attributed to artiodactyls such as cervids and cainotherids. The tetradactyl-pentadactyl tracks corresponding to carnivores are abundant in the site: the tracks of Felipeda ispp have been attributed to felidlike aluroids, those referred to Canipeda to herpestids (mongooses), and the ichnospecies Felipeda parvula has been defined in this site (Antón et al., 1993, 2004) (Fig. 2f). The bird tracks are tetradactyl and have different size. The 
largest ones have been related to herons. The Salinas de Añana tracks were probably produced in a lacustrine basin subject to sudden seasonal floods. The ichnosite is one of the best collections of Miocene vertebrate (and especially carnivore) tracks that are known in the world. A cast of the tracks is preserved in the MCNA of Vitoria-Gasteiz. Other copies are reposited at the UPV/EHU-EP of Leioa and in the American Museum of Natural History of New York.

Arrikrutz Cave (LIG PV65). (Fig. 1, No. 4; Tables 1,3). The Gesaltza-Arrikrutz cave system has a current development of $14 \mathrm{~km}$ within the sierra de Aizkorri, Gipuzkoa (Arriolabengoa et al., 2018). One of the galleries, explored by Ruiz de Arcaute \& San Martín (1967), yielded 1,440 fossil remains of cave bear (Ursus spelaeus), 15 remains of wild goat (Capra pyrenaica) and an upper first molar of woolly rhinoceros (Coelodonta antiquitatis) (Altuna, 1979; Altuna \& Mariezkurrena, 2010). The bears from Arrikrutz are, together with those of El Reguerillo (Madrid), the oldest of the Iberian Peninsula (marine isotope stage 6) (Torres, 2014). Additionally, the Gesaltza-Arrikrutz cave system has yielded the most complete cave lion (Panthera spelaea) skeleton from the Iberian Peninsula recovered so far (Fig. 1h), and the femur of an additional, larger, individual found at the Larrayoz gallery (Altuna, 1967, 1981). The fossils from Arrikrutz are housed at the Gordailua (Irun).

Kiputz site (LIG PV95). (Fig. 1, No. 5; Tables 1, 3). Kiputz IX is a Late Pleistocene site located close to Mutriku (Gipuzkoa). This site has yielded an abundant macromammal assemblage ( $>12,000$ remains), including ungulates and carnivores, as well as micromammals, birds and amphibians, and has been interpreted as a natural trap (Castaños et al., 2012). The stratigraphic sequence of ca. 4.5 $\mathrm{m}$ of depth shows a chronology ranging between 11,750 and 32,810 years BP, although most of the remains come from levels D and F, with dates ranging from 14,360 to 19,870 years BP (Castaños et al., 2012). Despite red deer (Cervus elaphus) being the most abundant taxon, this site has yielded the largest known assemblages of bison (Bison priscus) and reindeer (Rangifer tarandus) in the Iberian Peninsula (Castaños et al., 2006, 2009, 2012, 2014a, 2014b; GómezOlivencia et al., 2014), including a complete cranium of the former, unique in the Iberian Peninsula. The fossils from this site are housed at the Gordailua (Irun).

\subsubsection{Other sites included in the LIG-CAPV Inventory containing scarce but highly significant vertebrate fossils}

Peñacerrada/Urizaharra amber sites (LIG PV129, also CV010; Geosites FC009 and FC010). (Fig. 1, No. 6; Tables 1, 3). The Peñacerrada/Urizaharra-Moraza sites (Araba and Condado de Treviño) are considered to be one of the most important Early Cretaceous amber deposits in the world due to the high grade of the fossil resin and the number and quality of the preserved biological inclusions (Alonso et al., 2000; Delclós et al., 2007). The deposits are Albian in age. Most of the inclusions correspond to insects (flies, mosquitoes, wasps) and other arthropods, but a collection of dinosaur feathers is also known (material currently under study). The outcrop is qualified as Heritage of Cultural Interest (BIC: Bien de Interés Cultural) and Qualified Cultural Heritage (BCC: Bien Cultural Calificado) by the Basque Government. The amber and the named Yacimiento Paleontológico de Peñacerradal Urizaharra (Araba) were established as Monumental ensemble (Conjunto Monumental) on 1998 (Rodrigo et al., 2018), and catalogued as Spanish Geosites in 2008. The fossils are reposited at the MCNA of Vitoria-Gasteiz, some of them forming part of a permanent exposition.

Azkorriaga Fort site, Gorliz (LIG PV26). (Fig. 1, No. 7; Tables 1, 3). This outcrop of Gorliz (Biscay) is a small coastal promontory located on the cliffs of this town (300 m long, up to $180 \mathrm{~m}$ width, and $50 \mathrm{~m}$ height). Geologically, it is located in the northern flank of the Biscay Synclinorium and the promontory rocks mainly consist of Urgonian limestones, with abundant corals, rudists and other carbonate bioconstructors, originated in a shallow marine platform of over 100 million years (Early Cretaceous). In the overlying terrigenous series, known as the Macro-sequence 1 or Monte Grande Formation of the early-middle Albian, in the siliceous sandstones, interpreted as corresponding to a shallow marine environment linked to a coastal fan sedimentary system, dinosaur ichnites have been found (palaeoichnological data in Moratalla et al., 1994; further geological data in García-Mondéjar \& Pujalte, 1983; Robles et al., 1988). The ichnites are currently under study.

Lacustrine limestones of the Loza syncline (LIG PV51). (Fig. 1, No. 8; Tables 1, 3). The Eocene lacustrine limestones of Loza (Araba) appear in the centre of the syncline in the E-W direction and discordantly on a set of clays from the late Thanetian. Among the fossils found are ostracods, gastropods, charophytes and some vertebrates. The latter include otoliths of fish, crocodiles and other reptile remains (Murelaga et al., 2006). The fossils are housed at the UPV/EHU-EP of Leioa.

Murgia palustrine fossil site (LIG PV 137). (Fig. 1, No. 9; Tables 1, 3). A palustrine small intramontane basin originated atop of the extruding Triassic materials of the Murgia (Zuia, Araba) diapir during the OligoceneMiocene transition (López-Horgue \& Hernández, 2003). This endorheic basin was fed by braided alluvial channels draining from mountains that formed the diapiric rim. Channelized gravel beds and sandstones with coal beds 
are locally important near the diapiric rim, but towards the centre of the basin, the sedimentary succession is mainly composed of clays with carbonate concretions. These concretions bear what could be the best example of a Konservat-Lagerstätte in the Pyrenean area with exquisitely preserved articulated insects, crabs, fishes and flora remains showing delicate biological structures. The fishes here preserved show soft tissues and organs, such as quite complete digestive apparatus, scales and eye structures. These fishes are of high palaeoecological value since they are representatives of forms adapted to brackish conditions (Prolebias euskadiensis Gaudant, 2003) in a basin without sea connection. Triassic salt at the base of this lacustrine basin is in the likely origin of a higher salinity in freshwater environments. Fossil flora indicates subtropical conditions for early Miocene in this Murgia diapiric basin (Barrón et al., 2006). The fossils are preserved in the MCNA of Vitoria-Gasteiz and in the UPV/EHU-EP of Leioa.

\subsubsection{Vertebrate fossil sites with high to very high palaeontological interest that should be added to the LIG-CAPV Inventory}

Since the inventory of LIG from the CAPV was published in 2014, new studies have yielded palaeontological sites with high to very high interest, which should be the subject to geoconservation initiatives.

The Villaro Formation in the Arratia and Deba valleys (Biscay and Gipuzkoa). (Fig. 1, No. 10, 11; Tables 2, 3). Fish-bearing lutites of the Zeanuri site are not the only known fish fossil site in the studied area. Actually, Zeanuri beds are at the lower part of 1,100 m thick stratigraphic succession named Villaro Formation of Valanginian to Barremian age. This is composed of lutites and sandstones arranged in decimetric coarsening upward sequences that originated after progradation of delta lobes into a very shallow brackish coastal area. At least four intervals of lutites bearing fish remains are located through the sedimentary succession (see PoyatoAriza et al., 2000) outcropping in the sites Zeanuri 1 and 2, Artea 1 and 2 and Villaro (Biscay). Studied fishes come from the Zeanuri 1 site only. Mountain outcrops of the Villaro Formation between Zeanuri and Zeberio localities are today included within the Gorbeia Natural Park, a fact that looks ideal for a future preservational policy in the area. More recently, the motorway works in the Deba valley (Gipuzkoa) cut across the Villaro Formation, where new fossil fish remains were discovered in the Eskoriatza locality. Fishes are preserved in lutites of shallow marine origin that formed in the distal part of the

Table 3. Vertebrate fossil collections from the western Pyrenees with high to very high palaeontological interest. Abbreviations: A, Araba; Bi, Biscay; Bu, Burgos; G, Gipuzkoa; N, Navarre; T, Condado de Treviño. See repository abbreviations in the Introduction section. See the text for more details of the vertebrate fossil collections.

\begin{tabular}{lll}
\hline \multicolumn{1}{c}{ Vertebrate fossil collection } & \multicolumn{1}{c}{ Age } & Repository \\
\hline Arrikrutz Cave $(\mathrm{G})$ & Quaternary & Gordailua \\
Kiputz IX site (G) & Quaternary & Gordailua \\
Santa Isabel de Ranero Quarry (Bi) & Quaternary & AM \\
Punta Lucero Quarry (Bi) & Quaternary & AM \\
Koskobilo Quarry (N) & Quaternary & FA \\
Bardenas Reales fossil sites (N) & early to & FA, Aguilares Center \\
& middle Miocene & UPV/EHU-EP \\
Murgia palustrine fossil site (A) & early Miocene & MCNA \\
Salinas de Añana ichnosite (A) & early Miocene & MCNA, UPV/EHU-EP \\
Monteagudo macromammal fossil site (N) & early Miocene & FA, ICP \\
NW Ebro Basin ichnosites (N) & Oligocene-Miocene & UPV/EHU-EP \\
Pamplona Basin ichnosites (N) & late Eocene & CIFL, UPV/EHU-EP \\
Zambrana mammal fossil site (A) & late Eocene & MCNA, UPV/EHU-EP \\
Loza syncline (A) & Eocene & UPV/EHU-EP \\
Urbasa-Andia Natural Park (N) & middle Eocene & UPV/EHU-EP \\
Egues valley (N) & middle Eocene & UPV/EHU-EP \\
Quintanilla la Ojada Quarry (Bu) & Late Cretaceous & MCNA \\
Laño Quarry (T) & Late Cretaceous & MCNA \\
Gometxa and Vitoria Pass sites (A) & Late Cretaceous & MCNA \\
Aiara valley (Bi) & Late Cretaceous & AEA \\
Estella-Lizarra fossil site (N) & Early Cretaceous & Private coll., UPV/EHU-EP \\
Peñacerrada amber sites (A and T) & Early Cretaceous & MCNA \\
Zeanuri fish fossil site (Bi) & Early Cretaceous & MCNA, UPV/EHU-EP \\
Arratia and Deba valleys (Bi and G) & Early Cretaceous & UPV/EHU-EP \\
\hline
\end{tabular}


coastal areas of Zeanuri. The preservation is exceptional with nice articulated 3D bones of clupeomorphs. Many articulated remains of decimetre-sized fishes were taken by motorway workers, being now lost for the science. Scientists were advised and attended the site in order to take the most of the available information from the motorway cuts (sedimentary facies and fossils) (LópezHorgue, 2006) but just the day before the outcrops were buried by concrete structures and without enough time to make a good prospective dig and to talk to collectors for collaboration. A similar situation happened with the works for the High Speed Train in the Aramaio locality (Araba); here again some clupeomorph fish remains were obtained from lutites of the upper part of the Villaro Formation, coeval to those of the Eskoriatza locality. Train cuts were concrete covered here as well. Many fossil fishes from the Villaro Formation beds of Arratia and Deba valleys are housed at the collections of the UPV/EHU-EP (Leioa, Biscay).

The Santa Isabel de Ranero Cave (Carranza/ Karrantza, Biscay). (Fig. 1, No. 12; Tables 2, 3). This cave has yielded an abundant fossil record of the Middle Pleistocene bear Ursus deningeri, with a chronology of ca. $300 \mathrm{ka}$ (Torres et al., 2001, 2014). This collection includes one of the only two complete crania for this species in the Iberian Peninsula (Gómez-Olivencia et al., manuscript in preparation). The site where most of these bears were found was nearly completely excavated because it was in danger due to the visits of illegal excavators (Torres et al., 2001). The cave is currently closed for the protection of the bat colonies that inhabit this cavity and can be accessed when special permissions are granted during time periods that do not affect to the bat colony. The recovered vertebrate fossils are reposited at the AM of Bilbao (Biscay).

\subsubsection{Vertebrate fossil collections with high or very high palaeontological interest in the CAPV that should be subject to geoconservation initiatives}

There are vertebrate fossil collections that are not related to the LIG-CAPV Inventory, but exhibit high or very high palaeontological interest and should be subject to geoconservation strategies.

Late Cretaceous beds of the Aiara Valley (Araba). (Fig. 1, No. 13; Table 3). The Cenomanian succession near Amurrio is composed of a $750 \mathrm{~m}$ thick succession of marls, marly limestones and nodular limestones originated in a shallow marine platform. In the middle Cenomanian marls near the Izoria locality, a unique articulated bony fish of the Pachyrhizodontidae family has been found together with ammonites (López-Horgue et al., 2014). This specimen is the first described record of Crossognathiformes in the Iberian Peninsula, being the oldest evidence of modern actinopterygians in the region and a representative of the teleosteans that replaced the basal neopterygians fishes in a moment of major transgression worldwide (onset during the latest Albian to earliest Cenomanian in the studied area). The specimen (Aztarna-1) belongs to the collections of the AEA (Araba).

The Punta Lucero Quarry (Zierbena, Biscay). (Fig. 1, No. 14; Table 3). I. Libano found this site in 1987 during the quarrying works conducted in the building of the outer part of the port of Bilbao, drastically altering the NE flank of the Punta Lucero Mountain (GómezOlivencia et al., 2015). Part of the macro-mammal remains, including ungulates and carnivores, were preliminarily published by Castaños (1988). The indepth study of the Punta Lucero collection lead to the identification of three carnivore species for the first time in the western Pyrenees: the European jaguar Panthera gombaszoegensis, the scimitar-toothed cat Homotherium latidens and the wolf Canis mosbachensis (GómezOlivencia et al., 2015) (Fig. 2g). Stable isotope analysis points to resource partitioning between Punta Lucero cervids and bovids, while both stable isotope analysis and trophic modelling evidence resource overlap and interspecific competition among the two large-sized cats (Domingo et al., 2017). The biochronological assessment has proposed a chronology between 0.4 and 0.6 Ma for this collection, currently rendering it as the oldest Quaternary macro-mammal assemblage in western Pyrenees and one of the oldest of the whole Northern fringe of the Iberian peninsula (Álvarez-Lao, 2016). This site is currently destroyed and the fossil collection is reposited at the AM of Bilbao.

\subsubsection{Other vertebrate fossil sites from the Basque-Cantabrian Region in Navarre and Castile and León that should be subject to geoconservation initiatives}

Other vertebrate sites from the Basque-Cantabrian Region and the fossil collections recovered from these sites show high to very high palaeontological interest and should be subject to effective geoconservation initiatives by the Community of Castile and León. The two more relevant sites by their palaeobiodiversity and richness in vertebrate fossils are the Laño Quarry (Condado de Treviño) and the Quintanilla la Ojada Quarry (northern Burgos), both Late Cretaceous in age. Additionally, the impressive decimetresized fishes of the upper Albian of the Zufia Formation near Estella-Lizarra (Navarre) are a nice example of palaeontological heritage of key relevance. 
Zufia Formation, Estella-Lizarra (Navarre). (Fig. 1, No. 15; Tables 2, 3). The Zufia Formation is an extremely thick sedimentary succession of more than $1,500 \mathrm{~m}$ of late Albian age originated on the borders of the sinsedimentary Estella-Lizarra diapir. It is composed mainly of silty marls originated in a shallow marine platform with scattered sandstone beds of coastal origin and few beds of coral to foraminiferal limestones (López-Horgue et al., 1999). The upper part of the succession shows stratiform siderite concretions that bear ammonites, gastropods, bivalves, brachiopods, crabs and fishes exquisitely preserved. Fossil fishes are usually 40-60 cm long and $15-20 \mathrm{~cm}$ high, showing articulated bodies with very detailed fin bones, head bones and leptoid scales covering vertebrae. These fishes have not been studied yet but they may correspond to active swimmer teleosteans of the order Crossognathiformes. A nice collection of about 10 specimens is housed by a private collector near EstellaLizarra, being the most impressive collection of articulated fossil fishes of the Basque-Cantabrian Region. The study of these specimens is of vital importance since they are key in the understanding of the evolution of teleosteans in a moment of worldwide environmental changes. Some tiny remains are additionally housed at the UPV/EHU-EP collections in Leioa.

Gometxa and Vitoria Pass selachian sites. (Fig. 1, No. 16; Tables 2, 3). A large number of selachian teeth has been found in the Gometxa and Vitoria Pass sites, two productive areas from the upper Campanian strata of the Vitoria Sub-basin in the Navarre-Cantabrian Ramp of Araba (Corral, 2018). The Gometxa site is located in a small limestone quarry near Vitoria-Gasteiz where the Gomecha Member of the Vitoria Formation is exposed. It has yielded more than 120 teeth catalogued belonging to about 17 taxa of neoselachians. In the brick pits of the Vitoria Pass, the glauconitic marl beds of the Eguileta Member of the Montes de Vitoria Formation have yielded more than 130 teeth catalogued; they have been referred to 8 neoselachian taxa. The selachian fauna from these sites shows close affinities to that of the Kristianstad Basin in Sweden (Corral, 2018). The Campanian marine strata of the Vitoria Formation have also yielded fossil remains of enchodontids (bony fishes) and mosasaurids (squamates) (Corral et al., 2011).

Laño Quarry (Condado de Treviño). (Fig. 1, No. 17; Tables 2, 3). The vertebrate-bearing beds of the Laño Quarry are among the most noteworthy sites from the Late Cretaceous of Europe. Laño has yielded thousands of bones and teeth, including microfossils. The vertebrate remains occur at two different stratigraphic horizons within a continental to shallow marine succession of CampanianMaastrichtian age (Astibia et al., 1999). The lower horizon contains three fossiliferous levels composed mainly of fluvial sands and silts within an extensive braider river system. Based on magnetostratigraphic grounds, the Laño site is regarded as latest Campanian in age (Corral et al., 2016a). The diverse vertebrate fauna consists of nearly 40 species, including actinopterygians, lissamphibians, lepidosaurs, turtles, crocodyliforms, dinosaurs, pterosaurs, and mammals. Seven genera and ten species have been erected to date in Laño, among which taxa like the snake Herensugea, the turtles Dortoka and Solemys, the crocodiles Musturzabalsuchus and Acynodon (Fig. 2b), the dinosaur Lirainosaurus and the mammal Lainodon (see Pereda-Suberbiola et al., 2015; Pereda-Suberbiola, 2018; and references therein). This assemblage is representative of the late Campanian vertebrate faunas of southern Europe. On the other hand, the upper horizon of the Laño Quarry has yielded a shallow marine vertebrate association (Albaina site), which consists of at least 37 species of sharks and rays, actinopterygians, mosasaurids and plesiosaurs. Two genera and species of rhinobatoids and two new species of rhinobatids have been erected in Albaina. The Albaina association indicates a late (but not latest) Maastrichtian age. This is the most diverse assemblage of marine vertebrates found so far in the latest Cretaceous of the Ibero-Armorican Domain. It shows a mixture of both southern Tethyan and northern European boreal species, but also containing some particular taxa, such as the rhinobatoids Ataktobatis and Vascobatis (Cappetta \& Corral, 1999; Pereda-Suberbiola et al., 2015). The fossil remains of the Laño Quarry are housed at the MCNA of Vitoria-Gasteiz.

Quintanilla la Ojada Quarry (Burgos). (Fig. 1, No. 18; Tables 2, 3). Upper Maastrichtian shallow littoral deposits of the Quintanilla la Ojada Quarry have yielded a diverse marine vertebrate assemblage. The vertebratebearing beds are related to a transgressive lag (Berreteaga, 2008). Fossil remains of at least 30 different species, including selachians (sharks, rays), actinopterygians (teleosteans, pycnodontiforms, amiiforms and) and mosasaurids, are known (Berreteaga et al., 2011; Corral et al., 2016b). The fossil association is close to that of Albaina, but its age may be slightly older (early late Maastrichtian). Minor taxonomic differences may be due to ecological preferences (Corral, 2018; and a work currently in progress). The ichthyofauna of Quintanilla la Ojada (as well as that of Albaina) constitutes an example of the replacement process of the actinopterygian composition in the aquatic ecosystems during the latest Cretaceous, when specialized forms of relict, formerly abundant, basal neopterygians were replaced by teleosteans, probably in relation to major marine transgressive episodes (LópezHorgue et al., 2014, 2018). The teleostean-based new stock constitutes the basis of the Late Cretaceous, Cenozoic, and Recent ichthyofaunas. The fossil remains are preserved in the collections at the MCNA of Vitoria-Gasteiz. 


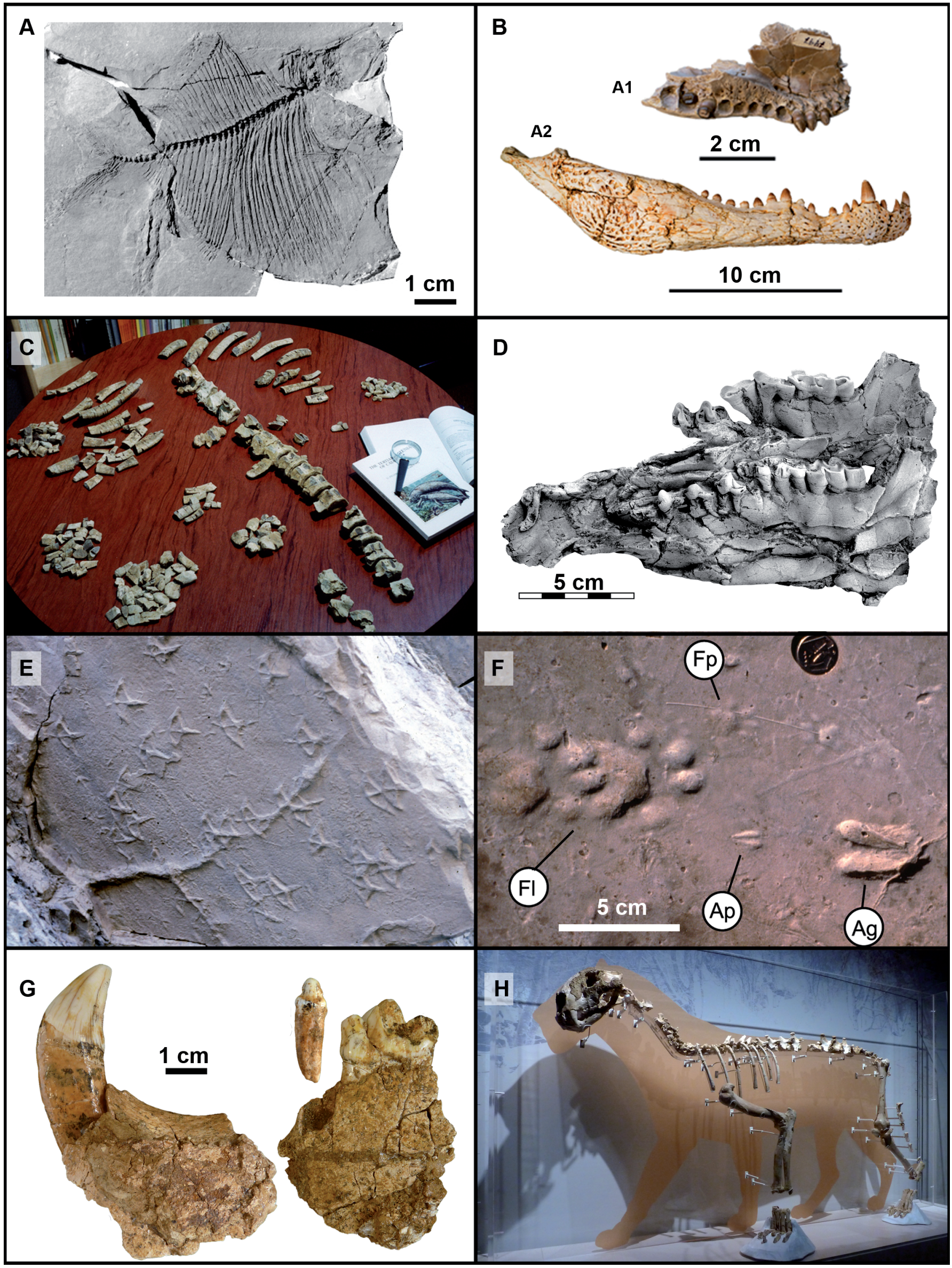




\subsubsection{Other vertebrate fossil collections from the Basque-Cantabrian Region in Navarre that should be subject to geoconservation initiatives}

Navarre shows a great geodiversity, but there is currently no inventory of geological interest sites (LIG) or other geoconservation figure.

Sirenian fossils from the Urbasa-Andia Natural Park (Navarre). (Fig. 1, No. 19; Table 3). Two localities from western Navarre have provided Eocene aquatic mammalian fossils: Arrasate (Urbasa plateau) and Lezaun (Andia plateau). Geologically, the remains were recovered from the Urbasa-Andia Formation. This formation was deposited in a carbonate ramp environment on the southern margin of the marine gulf (Bay of Biscay). The age of the fossils of Lezaun is late Lutetian (middle Eocene, SBZ 16 biozone), whereas those from Arrasate are dated as late Lutetian-early Bartonian (SBZ 16-SBZ 17 biozone). The most abundant sirenian material comes from Arrasate and consists of axial elements and one appendicular bone. The sirenian remains of these localities correspond to the oldest sirenian fossils from Eurasia, together with the remains from the Castejón de Sobrarbe site in Huesca (DíazBerenguer et al., 2018a). Both the Arrasate and Lezaun sites contain a great amount of geological (see Payros et al., 2010 for an interpretation of shallow-marine carbonate sedimentary environments developed under greenhouse conditions) and palaeontological information (rich invertebrate fossil assemblages). Sirenian fossil collections exhibit a high palaeontological value and should be subject to geoconservation initiatives. These fossils are temporarily deposited for study in the UPV/EHU-EP of Leioa.

Koskobilo Quarry, Olazti (Navarre). (Fig. 1, No. 20; Table 3). The Koskobilo Quarry yielded important Middle to Late Pleistocene archaeological-palaeontological remains. More than 25 species were identified (Ruiz de Gaona, 1941), with especial attention to the first Castor fiber fossil remains described in the Iberian Peninsula (Crusafont \& Villalta, 1948). Additionally, a recent revision of the material resulted in the identification of four, absent or rare, new taxa in the western Pyrenees: Cuon sp., Macaca sylvanus, Ursus thibetanus and Megacerini indet. (Arlegi et al., 2018). The lithic collection can be ascribed to the Upper Palaeolithic, Solutrean and final Upper Magdalenian/Azilian, with few older pieces related to Lower or early Middle Palaeolithic cultures. The site, which probably holds the most important Pleistocene faunal fossil remains of Navarre, was destroyed during the quarry exploitation. The collections are housed at the FA of Pamplona-Iruñea (Navarre).

\subsection{Pamplona Basin}

\subsubsection{Vertebrate fossil sites from the Pamplona Basin (Navarre) that should be subject to geoconservation initiatives}

The abundance and diversity of vertebrate ichnites found in Navarre are noteworthy. Bird and mammal tracks are known in about a dozen of Cenozoic ichnosites from both the Pamplona Basin and the NW of the Ebro Basin (Astibia et al., 2007; Díaz-Martínez et al., 2018).

Avian ichnosites from the Pamplona Basin (Navarre). (Fig. 1, No. 21; Tables 2, 3). Several late Eocene sites from the Pamplona Basin and surroundings (including the Aranguren-Itzaga syncline) have yielded avian tracks (see Astibia et al., 2007, 2017; Díaz-Martínez et al., 2018). The avian track assemblage is dominated by aquatic forms, being especially abundant in the Priabonian coastal deposits of the Gendulain Formation. Tetradactyl footprints with interdigital web impressions from the late Eocene of Xabier/ Javier-Ledea/Liedena allowed defining the ichnospecies

Figure 2. Selected vertebrate fossils from the western Pyrenees (Basque-Cantabrian Region and Pamplona Basin). a) Early Cretaceous clupeomorph fish Ezkutuberezi carmeni (holotype), from the Zeanuri fish fossil site (LIG PV131), Biscay, modified from Poyato-Ariza et al. (2000). b) Late Cretaceous crocodyliforms from the Laño Quarry (Condado de Treviño), modified from Pereda-Suberbiola et al. (2015): A1, left maxilla of Acynodon iberoccitanus (holotype) in ventral view; A2, right mandible of Musturzabalsuchus buffetauti paratype in lateral view (photos: J.C. Corral and F. Ortega). c) Middle Eocene sirenian ribs and vertebrae from Ardanatz (Navarre), modified from Díaz-Berenguer et al. (2018b), photo: H. Astibia. Anteroposterior length of vertebral centra between 34 and $50 \mathrm{~mm}$. d) Mandible (holotype) of Iberolophus arabensis from the late Eocene site of Zambrana (LIG PV128), Araba, modified from Badiola \& Cuesta (2008). e) Block from the Xabier/Javier (Navarre), where the bird ichnospecies Leptoptilostipus pyrenaicus (epireliefs) has been described, modified from Payros et al. (2000), photo: H. Astibia. The length of these tracks is between 80 and $113 \mathrm{~mm}$. f) Vertebrate ichnofossils from the early Miocene site of Salinas de Añana (LIG PV130), Araba, modified from Díaz-Martínez et al. (2018): Fp, Felipeda parvula; Fl, Felipeda lynx; Ap, small artiodactyl; Ag, large artiodactyl; photo: J.C. Corral. g) Left mandible and dentition of the scimitar-toothed cat Homotherium latidens from the Middle Pleistocene site of Punta Lucero, Biscay, modified from Gómez-Olivencia et al. (2015). h) Exhibition of the left part of the complete skeleton of a Panthera spelaea from Arrikrutz (LIGPV 165), Gipuzkoa. As a scale, the humerus has a maximum length of $371 \mathrm{~mm}$ (Altuna, 1981). 
Leptoptilostipus pyrenaicus by Payros et al. (2000) (Fig. 2e). These tracks correspond to anseriform or circoniiform birds. Other tetradactyl footprints without interdigital web impressions from the same area have been attributed to Gruipeda. Finally, tridactyl footprints from the late Eocene of Xabier and Ibarzabaltza/Zabalza de Ibargoiti have been referred to the ichnotaxon Koreanaornis (Díaz-Martínez et al., 2018). Both the Gruipeda and Koreanaornis prints of Navarre may be due to charadriiform avian taxa. The Xabier-Ledea outcrops, although partially destroyed by highway works, could constitute a LIG of high palaeontological value. The ichnofossil collections are housed in the CIFL (Irunberri, Navarre) and provisionally in the UPV/EHU-EP (Leioa, Biscay).

\subsubsection{Vertebrate fossil collections from the Pamplona Basin with high to very high palaeontological interest to should be subject to geoconservation initiatives}

Sirenian sites form the Egues valley/Eguesibar (Navarre). (Fig. 1, No. 22; Table 3). Eocene sirenian fossils (vertebrae and ribs) have been found in the middle Eocene (Bartonian) of the Pamplona Basin in two outcrops of the Egues valley: Ardanatz and Uztarrotz, both located near the city of Pamplona/Iruñea (Astibia et al., 2005, 2006) (Fig. 2c). All the remains are well preserved and were provisionally attributed to the Dugongidae; it cannot be ruled out that the fossils correspond to a basal dugongid close to the genus Prototherium. The vertebral series belonging to the same individual and found in Ardanatz come from the deposits in the transition between the Ardanatz Sandstone and the Ilundain Marl formations, are early Bartonian in age, and were interpreted as corresponding to a restricted marine platform with locally abundant macrofossil invertebrate associations (Astibia et al., 2016). Near Uztarrotz, in the Pamplona Marl Formation, which is situated below stratigraphically than the above-mentioned formations, around thirty sirenian remains were found in prodelta deposits. The Pyrenean domain contains one of the most complete fossil record of sirenians in Europe (Díaz-Berenguer et al., 2018b), but that of the western Pyrenees is still scarce. The remains recovered in the Pamplona Basin and in the Urbasa-Andia Plateau (Basque-Cantabrian Region), range from the late Lutetian to the early Bartonian (middle Eocene, SBZ 16 and 17 biozones). These remains, together with those found in the Ainsa Basin, in the Castejón de Sobrarbe site (Huesca; middle Lutetian, SBZ 15 biozone; DíazBerenguer et al., 2018a), correspond to the oldest sirenian specimens of the northeastern Atlantic coast (Bay of Biscay). Both the fossil collections of Navarre and Huesca are important finds and essential to study the first stages of the evolutionary history of the sirenian mammals.
The findings of Navarre correspond to punctual fossil accumulations and there is no any outcrop that might become part of the LIG Inventory. However, the sirenian fossils have a high patrimonial value and should be subject to geoconservative initiatives. The fossils from Navarre are temporarily deposited in the UPV/EHU-EP of Leioa.

\subsection{NW Ebro Basin}

\subsubsection{Vertebrate fossil sites from the $N W$ Ebro Basin in Navarre with high to very high palaeontological interest that should be subject to geoconservation initiatives}

Oligocene and early Miocene mammal and bird ichnosites (Navarre). (Fig. 1, No. 23; Tables 2, 3). Mammal ichnites have been discovered in the Oligocene and in the lower Miocene deposits of Navarre (see Astibia et al., 2007; Díaz-Martínez et al., 2018). Tridactyl perissodactyl tracks similar to those of Plagiolophustipus are known in the lower Oligocene fluviatile rocks of the Mués Sandstone of Olexoa/Olejua. Similar but not so well-preserved equoid tracks have been found in the fluviatile deposits of the lower Oligocene Rocaforte Sandstone near Oibar/Aibar and Sada, and in the fluviatilepalustrine floodplain deposits of the lower Miocene Ujué Formation of Desoio/Desojo and Los Arcos/Arkueta. Tracks that look like those of Rhinoceripeda are known in the lower Miocene (Ramblian) palustrine limestones in the transition of the Marcilla and Lerín formations of Kaparroso. Didactyl trackways of entelodontid artiodactyls (Entelodontipus) occur in fluviatile-palustrine beds of the Oligocene Mués Sandstone of Olkotz (Astibia et al., 1994). Large didactyl tracks of artiodactyls, possibly related to the ichnotaxon Pecoripeda, have been discovered in the lower Miocene alluvial fan deposits of the UncastilloPerdón Formation of Altzorritz. In addition, tridactyl avian (Charadriiformes-like) tracks have been found in a number of the above-mentioned outcrops: e.g., in the Oligocene Mués Formation of Etaio and in the lower Miocene Ujué Formation of Los Arcos/Arkueta (Murelaga et al., 2007; Díaz-Martínez et al., 2018). Part of these ichnofossil collections is provisionally housed at the UPV/EHU-EP of Leioa.

Monteagudo macromammal fossil site (Navarre). (Fig. 1, No. 24; Tables 2, 3). The Yeseras de Monteagudo site has great historical value since it is the first palaeontological site with non-Quaternary remains found in Navarre and the only one that has provided abundant fossils of large mammals, such as mastodons. It was discovered in the 1910s by the Augustinian Fray Lacarra. Later, the Jesuit Longinos Navás collected fossil material 
in the quarry and published it, which motivated the interest of palaeontologists such as Crusafont and Villalta in the 1940s. They collaborated with the Piarist Ruiz de Gaona, who was in charge of recovering all the fossil remains he could (Ruiz de Gaona et al., 1946). After of the exploitation of the gypsum, the area became a rubbish dump, but the research was resumed later with the study of the fossil collections housed at the FA of Pamplona-Iruñea (Navarre) and at the palaeontological museum of Sabadell (ICP), Barcelona. A few Monteagudo fossils are deposited in Valladolid and Zaragoza. The fossiliferous beds are gypsum, clays and sandstones of lacustrine origin from the early Miocene (Aragonian, about $17 \mathrm{Ma}$ ). The fossils indicate a mammalian fauna composed of proboscideans, primitive equids, rhinos, artiodactyls (suids and ruminants) and large carnivores (Astibia et al., 1987). Although the fossiliferous deposits have not been found, there is evidence of the location of one of the gypsum quarries exploited in the past. The beginning of the recovery of the place has been carried out through the local project LIM (Sites of Municipal Importance), and an interpretative area for geotourist use has been developed.

Bardenas Reales fossil sites (Navarre). (Fig. 1, No. 25; Tables 2, 3). The Bardenas Reales de Navarra/Nafarroako Errege Bardeak are located in the northwestern sector of the Ebro Basin. They are an international reference at a landscape and geological level that was declared a protected natural area with the rank of Natural Park in 1999, and incorporated into the UNESCO World Network of Biosphere Reserves in 2000 (Larrasoaña et al., 2018). It has also been declared a Special Area of Conservation into the Natura 2000 Network. In the Bardenas Reales, a sedimentary series of 700 meters thick, deposited in delta and lacustrine environments during the lower and middle Miocene, is known. These deposits have provided a large amount of fossil material, including remains of about 80 vertebrate taxa (cypriniform fish, amphibians, lizards, snakes, amphisbaenians, crocodiles, turtles, birds and mammals: insectivorous, bats, rodents, lagomorphs, perissodactyls and artiodactyls), and 25 taxa of charophytes and ostracods. To date, four new palaeontological species have been described: two species correspond to the turtles Chelydropsis and Ptychogaster, and two to the dormouse Vasseuromys (see Murelaga et al., 2002, 2004; SuarezHernando et al., 2018; and references). In addition, avian eggshell remains and tracks of both birds and mammals have been found. Palaeoenvironmental reconstructions suggest a landscape with areas of open forest surrounding important freshwater bodies (lakes), where a warm subtropical climate prevailed. This landscape, 15 to 20 $\mathrm{Ma}$, was similar to the current one in the African savannah. Fossils are preserved in the FA of Pamplona-Iruñea (Navarre). Some of them are provisionally housed at the UPV/EHU-EP of Leioa (Biscay).
Vertebrate fossil tracks (birds and artiodactyls). Bird and artiodactyl tracks are found in the Miocene of the Bardenas Reales de Navarra Natural Park also present high to very high palaeontological interest and should be subject to geoconservation initiatives. The bird tracks are preserved in sandstone blocks of the Lerín Formation of 20.4 Ma in age (Agenian, early Miocene) according to the magnetostratigraphic data. The footprints, which measures more than $100 \mathrm{~mm}$ in length, was classified as Uvaichnites riojana and related with crane-like taxa (Gruidae) (DíazMartínez et al., 2012, 2016). It is considered that the sandstone blocks are palaeochannels of a distal alluvial, muddominated floodplain. The artiodactyl tracks are preserved in trampling surfaces of the Tudela Formation (Miocene), and are currently under study. The blocks with bird tracks from the Bardenas Reales are deposited in the Aguilares Information Center of the Bardenas Reales of Navarre Natural Park (Community of the Bardenas Reales, Navarre).

\section{FINAL CONSIDERATIONS}

The geoconservation designations (e.g., LIG, geosites) are an important step in the study of the palaeontological heritage of a territory, but do not guarantee the protection and conservation of the palaeontological sites or the fossil collection recovered in them. For that, it is necessary to design a geoconservation strategy of this palaeontological heritage, taking into account all the problems that may exist in each site and/or with each fossil collection. These problems can be related, for example, to the vulnerability or fragility of the fossil outcrop, with the risk of plundering of fossils, or with the different guidelines of action and legislation that may exist in the case of some palaeontological sites (Fernández-Martínez, 2018). In some territories, only the Quaternary palaeontological sites have been traditionally subject to a conservation initiative (Moreno-García, 2018). These sites are or have been managed through Cultural Heritage and the fossils, in the best cases, are preserved in Archaeological Museums. It is important to highlight that it is necessary to develop a methodology that values also the fossil collection with high heritage value: once recovered from the fossil sites, they should be included in the geoconservation initiatives (e.g., Cobos, 2011; FernándezMartínez, 2018). All the palaeontological heritage of movable type (fossil collections) should be housed in museums that comply with current legislation and ICOM (International Council of Museums) rules (Vegas et al., 2018). If the fossil collections are temporarily in public research or administration institution, or if the collection is private, there should be a common inventory of this movable palaeontological heritage and proposals for future strategies that ensure its correct conservation and use. 
In this work, we have focused on the most representative vertebrate fossil record and the palaeontological heritage (sites and collections) from the Basque-Cantabrian Region and adjacent areas (Pamplona Basin and NW Ebro Basin), including territories from the Autonomous Community of the Basque Country (CAPV), the Chartered Community of Navarre and the north of the Community of Castile and León. In the studied area, only in the CAPV exist an Inventory of Geological Interest Sites (LIG). Here we have described the LIG-CAPV which include the vertebrate palaeontological sites and have proposed other sites that could be further included into the LIG Inventory, or into another geoconservation initiative, both inside and outside of this territory. We highlight also that there are some vertebrate fossil collections with high to very high palaeontological interest that do not come from any LIG but also should be included in conservation strategies of the palaeontological heritage.

One of the actions planned for the future is to collaborate with the administration involved in the management of the movable palaeontological heritage (the fossil collections) of the studied area, beginning with that of the CAPV. Firstly, we need to have a common inventory of this movable palaeontological heritage housed in all public and private centres. In addition to those mentioned in this work, there are other vertebrate fossil collections (e.g., from the Hontza Museoa, in Mañaria, Biscay, or the Luberri Museoa, in Oiartzun, Gipuzkoa) that will be incorporated in a future inventory. The inventory should be agreed with the technicians who managed the palaeontological heritage in the Basque Government. In order to create this inventory, we are planning to supervise several End-of-Degree Projects (or similar projects) to catalogue small collections, and also to request a technical support staff to the administration for managing large collection of fossils like that from the UPV/EHU. One this inventory is done, it would be convenient to create a network, available for the curators and researchers. Finally, the impulse by the administration of initiatives for managing this movable palaeontological heritage, which guarantees the preservation and public access of the fossil collections, will be necessary.

One of the most important uses of the palaeontological heritage is its usefulness as a didactic, educational and cultural tool (e.g., Cobos, 2011; Canudo, 2018), since they are the only historical archive that offers information about the geological and biological history of the Earth. For the scientific and cultural dissemination of the palaeontological heritage, there should be greater collaboration between the palaeontologists that have valued the palaeontological assents and the technicians and institutions that manage them. It would be convenient for these technicians to have knowledge of Palaeontology, as it is occur, for example, in the Autonomous Community of Aragon and also in the Basque Country. To develop the informative and educational tasks of this natural heritage, it would be interesting to have more budgetary items in order to carry out, for instance, the publication of books, talks, geo-routes or other activities in the field or in the urban area (guided tours to see fossils), school workshops, etc. These tasks are very important for the society awareness with geology in general and palaeontology in particular. In this sense, the authors of this work have organized several conferences and workshops in the UPV/EHU and primary and secondary schools, published some articles and books (e.g., Bodego et al., 2014; Badiola et al., 2018a) and organized some field activities (e.g., Geolodía). We are planning to continue doing these activities in the future.

\section{ACKNOWLEDGEMENTS}

This research was supported by the Gobierno Vasco/ Eusko Jaurlaritza (research group IT-1044-16) and the Universidad del País Vasco/Euskal Herriko Unibertsitatea (UPV/EHU, research groups PPG17/05 and GIU18/163). The authors also acknowledge the support of the research projects CGL2017-85038-P of the Ministerio de Economía, Industria y Competitividad and the research project PGC2018-093925-B-C33 of the Ministerio de Ciencia, Innovación y Universidades of Spain, and the European Regional Development Fund (ERDF). We thank the reviewers Drs Alberto Cobos (Fundación Conjunto Paleontológico de Teruel-Dinópolis) and Francisco Ortega (UNED, Madrid) for their valuable comments and suggestions that have helped to improve the manuscript.

\section{REFERENCES}

Alonso, J., Arillo, A., Barrón, E., Corral, J.C., Grimalt, J., López, J.F., López, R., Martínez-Delclòs, X., Ortuño, V., Peñalver, E. \& Trincão, P.R. 2000. A new fossil resin with biological inclusions in Lower Cretaceous deposits from Álava (Northern Spain, Basque-Cantabrian Basin). Journal of Paleontology, 74, 158-178; doi: 10.1666/0022-3360(2000)074<0158:ANFRWB>2.0.CO;2.

Altuna, J. 1967. Hallazgo de un esqueleto de león de las cavernas en la cueva de Arrikrutz (Oñate-Guipúzcoa). Munibe, 19, 331-332.

Altuna, J. 1979. Nuevo hallazgo de rinoceronte lanudo (Coelodonta antiquitatis Blum.) en Guipúzcoa. Munibe, 31, 281-282.

Altuna, J. 1981. Fund eines Skeletts des Höhlenlöwen (Panthera spelaea Goldfuss) in Arrikrutz, Baskenland. Bonner zoologische Beiträge, 32, 31-46.

Altuna, J. \& Mariezkurrena, K. 2010. Tafocenosis en yacimientos del País Vasco con predominio de grandes carnívoros. Consideraciones sobre el yacimiento de 
Amalda. In: Actas de la $1^{a}$ Reunión de Cientificos sobre Cubiles de Hienas (y otros Grandes Carnívoros) en los Yacimientos Arqueológicos de la Península Ibérica (eds. Baquedano, E. \& Rosell, J.). Zona Arqueológica, 13. Museo Arqueológico Regional, Alcalá de Henares, 214228.

Álvarez-Lao, D.J. 2016. Middle Pleistocene large-mammal faunas from North Iberia: palaeobiogeographical and palaeoecological implications. Boreas, 45, 191-206; doi: 10.1111/bor. 1214 .

Antón, M., López, G. \& Santamaría, R. 1993. Estudio preliminar de la icnofauna miocena del yacimiento de Salinas de Añana (provincia de Álava). In: Comunicaciones de las IX Jornadas de Paleontología (ed. González Donoso, J.M.), Málaga, 23-28.

Antón, M., López, G. \& Santamaría, R. 2004. Carnivore trackways from the Miocene site of Salinas de Añana (Alava, Spain). Ichnos, 11, 371-384; doi: 10.1080/10420940490444951.

Arlegi, M., Rios-Garaizar, J., Rodríguez-Hidalgo, A., LópezHorgue, M.A. \& Gómez-Olivencia, A. 2018. Koskobilo (Olazti, Nafarroa): nuevos hallazgos y revisión de las colecciones. Munibe (Antropologia-Arkeologia), 69, 21-41.

Arriolabengoa, M., Abarrategi, B., Dorado, J., Eraña, C., Olalde, A., Pereda, L., Azkoaga, X. \& Ugarte, S. 2018. Leize-ikerlariak (Espeleología). In: Arrikrutz. Arrikrutzko Lehoia. El León de Arrikrutz (ed. Agirre-Mauleon, J.). Sociedad de Ciencias Aranzadi, Donostia-San Sebastián, 50-71, 136-144.

Astibia, H., Mazo, A.V. \& Santafé-Llopis, J.V. 1987. Los macromamíferos del Mioceno medio de las Yeseras de Monteagudo (Depresión del Ebro, Navarra). In: Actas del IV Congreso Latinoamericano de Paleontología, Bolivia, Memorias 1, 415-441.

Astibia, H., Valle de Lersundi, J. del. \& Murelaga, X. 1994. Icnitas de artiodáctilos (Mammalia) del Paleógeno de Olcoz (Depresión del Ebro, Navarra). Estudios Geológicos, 50, 119-126.

Astibia, H., Corral, J.C., Murelaga, X., Orue-Etxebarria, X. \& Pereda-Suberbiola, X. (coords.). 1999. Geology and palaeontology of the Upper Cretaceous vertebrate-bearing beds of the Laño quarry (Basque-Cantabrian Region, Iberian Peninsula). Estudios del Museo de Ciencias Naturales de Álava, 14 (Número especial 1), 1-380.

Astibia, H., Aranburu, A., Pereda-Suberbiola, X., Murelaga, X., Sesé, C., Cuesta, M.A., Moyà-Solà, S., Baceta, J.I., Badiola, A. \& Köhler, M. 2000. Un nouveau site à vertébrés continentaux de l'Eocène supérieur de Zambrana (Bassin de Miranda-Treviño, Álava, Pays Basque). Geobios, 33, 233-248; doi: 10.1016/S0016-6995(00)80021-2.

Astibia, H., Payros, A., Pereda-Suberbiola, X., Elorza, J., Berreteaga, A., Etxebarria, N., Badiola, A. \& Tosquella, J. 2005. Sedimentology and taphonomy of sirenian remains from the Middle Eocene of the Pamplona Basin (Navarre, Western Pyrenees). Facies, 50, 463-475; doi: 10.1007/ s10347-004-0026-5.

Astibia, H., Pereda-Suberbiola, X., Bardet, N., Payros, A., Berreteaga, A. \& Badiola, A. 2006. Nuevos fósiles de sirenios en el Eoceno medio de la Cuenca de Pamplona (Navarra). Revista Española de Paleontología, 21, 79-91. Astibia, H., Pereda-Suberbiola, X., Payros, A., Murelaga, X., Berreteaga, A., Baceta, J.I. \& Badiola, A. 2007. Bird and mammal footprints from the Tertiary of Navarre (western Pyrenees). Ichnos, 14, 175-184; doi: 10420940601049917.

Astibia, H., Payros, A., Ortiz, S., Álvarez-Pérez, G., Badiola, A., Bardet, N., Berreteaga, A., Bitner, M.A., Calzada, S., Corral, J.C., Díaz-Martínez, I., Merle, D., Pacaud, J.M., Pereda-Suberbiola, X., Pisera, A., Rodríguez-Tovar, J. \& Tosquella, J. 2016. Fossil associations from the Middle and Upper strata of the Pamplona Basin and surrounding areas (Navarre, western Pyrenees). Journal of Iberian Geology, 42, 7-28; doi: 10.5209/rev_JIGE.2016.v42.nl.51601.

Astibia, H., Rodríguez-Tovar, F.J., Díaz-Martínez, I., Paryos, A. \& Ortiz, S. 2017. Trace fossils from the Middle and Upper Eocene (Bartonian-Priabonian) molasse deposits of the Pamplona Basin (Navarre, western Pyrenees): palaeoenvironmental implications. Geological Journal, 52, 327-349; doi: 10.1002/gj.2763.

Badiola, A. 2004. Estudio paleontológico del yacimiento del Eoceno Superior de Zambrana (Álava, Región VascoCantábrica). Tafonomía, paleobiología de mamíferos e implicaciones Biocronológicas. Ph.D. Thesis, Universidad del País Vasco/Euskal Herriko Unibertsitatea, Leioa, 417 pp. (unpublished).

Badiola, A. \& Cuesta, M.A. 2008. New endemic Eocene equoids from the Iberian Peninsula (Western Europe). Journal of Vertebrate Paleontology, 28, 1149-1161; doi: 10.1671/0272-4634-28.4.1149

Badiola, A., Pereda-Suberbiola, X. \& Cuesta, M.A. 2005. Una nueva especie de Pachynolophus (Mammalia, Perissodactyla) de Zambrana (Álava, Región VascoCantábrica). Análisis filogenético de Pachynolophus y primera cita en el Eoceno superior de la Península Ibérica. Geobios, 38, 1-16; doi: 10.1016/j.geobios.2003.07.005.

Badiola, A., Berreteaga, A., Pereda-Suberbiola, X., Elorza, J., Astibia, H. \& Etxebarria, N. 2009a. Taphonomy of vertebrate fossil assemblages from swampy circum-lake environments: an example from the Late Eocene of Zambrana (Iberian Peninsula). Palaios, 24, 522-534; doi: 10.2110/palo.2008.p08-126r.

Badiola, A., Checa, L1., Cuesta, M.A., Quer, R., Hooker, J.J. \& Astibia, H. 2009b. The role of new Iberian finds in understanding European Eocene mammalian palaeobiogeography. Geologica Acta, 7, 243-258; doi: 10.1344/105.000000281.

Badiola, A., Gómez-Olivencia, A. \& Pereda-Suberbiola, X. (eds.). 2018a. Registro Fósil de los Pirineos Occidentales. Bienes de Interés Paleontológico y Geológico. Proyección Social. Servicio Central de Publicaciones del Gobierno Vasco, Vitoria-Gasteiz, 300 pp.

Badiola, A., Perales-Gogenola, L. \& Díaz-Berenguer, E. 2018b. La radiación cenozoica de los mamíferos: un viaje a los ecosistemas tropicales del Eoceno. In: Registro Fósil de los Pirineos Occidentales. Bienes de Interés Paleontológico y Geológico. Proyección Social (eds. Badiola, A., Gómez-Olivencia, A. \& Pereda-Suberbiola, 
X.). Servicio Central de Publicaciones del Gobierno Vasco, Vitoria-Gasteiz, 117-140.

Barrón, E., Hernández, J.M., López-Horgue, M.A. \& AlcaldeOlivares, C. 2006. Palaeoecology, biostratigraphy and palaeoclimatology of the lacustrine fossiliferous beds of Izarra Formation (Lower Miocene, Basque-Cantabrian Basin, Álava province, Spain) based on palynological analysis. Revista Española de Micropaleontología, 38, 321-338.

Berreteaga, A. 2008. Estudio estratigráfico, sedimentológico y paleontológico de los yacimientos con fósiles de vertebrados del Cretácico final de la Región VascoCantábrica. Ph.D. Thesis, Universidad del País Vasco/Euskal Herriko Unibertsitatea, Leioa, 410 pp. (unpublished).

Berreteaga, A., Poyato-Ariza, F.J. \& Pereda Suberbiola, X. 2011. A new actinopterygian fauna from the latest Cretaceous of Quintanilla la Ojada (Burgos, Spain). Geodiversitas, 33, 285-301.

Bodego, A., López-Horgue, M., Astibia, H., Badiola, A., Berreteaga, A., Corral, J.C., Martínez-García, B., Ortiz, S., Pereda-Suberbiola, X., Rofes, J. \& Suarez-Hernando, O. 2014. Registro fósil de la Región Vasco-Cantábrica y áreas adyacentes de los Pirineos Occidentales. In: Geología de la Cuenca Vasco-Cantábrica (eds. Bodego, A., Mendia, M., Aranburu, A. \& Apraiz, A.). Servicio Editorial de la Universidad del País Vasco (UPV/EHU), Bilbao, 141-155.

Canudo, J.I. 2018. El Museo de Ciencias Naturales de la Universidad de Zaragoza como instrumento en la docencia universitaria. In: Registro Fósil de los Pirineos Occidentales. Bienes de Interés Paleontológico y Geológico. Proyección Social (eds. Badiola, A., GómezOlivencia, A. \& Pereda-Suberbiola, X.). Servicio Central de Publicaciones del Gobierno Vasco, Vitoria-Gasteiz, 277-289.

Cappetta, H. \& Corral, J.C. 1999. Upper Maastrichtian selachians from the Condado de Treviño (BasqueCantabrian Region, Iberian Peninsula). Estudios del Museo de Ciencias Naturales de Álava, 14 (Número especial 1), 339-372.

Castaños, P. 1988. Estudio de los restos de la cantera de Punta Lucero (Abanto y Ciervana, Bizkaia). Kobie (Serie Paleoantropología), 17, 157-165.

Castaños, J., Castaños, P. \& Murelaga, X. 2006. Estudio osteométrico preliminar de los restos de ciervo (Cervus elaphus) del yacimiento paleontológico del Pleistoceno Superior de Kiputz IX (Mutriku, Gipuzkoa). Geogaceta, 40, 163-166.

Castaños, J., Castaños, P., Murelaga, X., Alonso, A., Ortega, L.A., Zuluaga, M.C. \& Saez de Lafuente, X. 2009. Estudio morfométrico comparativo de la escápula y húmero de ciervo (Cervus elaphus) y reno (Rangifer tarandus) del Pleistoceno Superior. Geogaceta, 47, 41-44.

Castaños, J., Castaños, P., Murelaga, X. \& Alonso-Olazabal, A. 2012. Kiputz IX: un conjunto singular de bisonte estepario (Bison priscus Bojanus, 1827) del Pleistoceno Superior de la Península Ibérica. Ameghiniana, 49, 247261; doi: 10.5710/AMGH.v49i2(529).
Castaños, J., Castaños, P., Murelaga, X., Alonso-Olazabal, A., Ortega, L.A. \& Zuluaga, M.C. 2014a. Osteometric analysis of scapula and humerus for Rangifer tarandus and Cervus elaphus: a contribution to cervid discrimination (Late Pleistocene, Southern Pyrenees). Acta Palaeontologica Polonica, 59, 779-786; doi: 10.4202/app.2012.0027.

Castaños, J., Zuluaga, M.C., Ortega, L.Á., Murelaga, X., Alonso-Olazabal, A., Rofes, J. \& Castaños, P. 2014b. Carbon and nitrogen stable isotopes of bone collagen of large herbivores from the Late Pleistocene Kiputz IX cave site (Gipuzkoa, north Iberian Peninsula) for palaeoenvironmental reconstruction. Quaternary International, 339-340, 131-138; doi: 10.1016/j. quaint.2013.10.006.

Cobos, A. 2011. Los dinosaurios de Teruel como recurso para el desarrollo territorial. Ph.D. Thesis, Universidad del País Vasco/Euskal Herriko Unibertsitatea, Leioa, 584 pp. (unpublished).

Corral, J.C. 2018. Upper Cretaceous neoselachians from the Basque-Cantabrian Region (Northern Spain). Ph.D. Thesis, Universidad del País Vasco/Euskal Herriko Unibertsitatea, Leioa, 480 pp. (unpublished).

Corral, J.C., Bardet, N., Pereda Suberbiola, X. \& Arz, J.A., 2011. Depredadores marinos (osteictios, selacios y mosasaurios) en el Campaniense de la Cuenca VascoCantábrica. Paleontologia i Evolució, Memoria especial, 5, 83-87.

Corral, J.C., Pueyo, E.L., Berreteaga, A., RodríguezPinto, A., Sánchez, E. \& Pereda-Suberbiola, X. 2016a. Magnetostratigraphy and lithostratigraphy of the Laño vertebrate-site: implications in the uppermost Cretaceous chronostratigraphy of the Basque-Cantabrian region. Cretaceous Research, 57, 473-489; doi: 10.1016/j. cretres.2015.07.015.

Corral, J.C., Berreteaga, A. \& Cappetta, H. 2016b. Upper Maastrichtian shallow marine environments and neoselachian assemblages in North Iberian palaeomargin (Castilian Ramp, Spain). Cretaceous Research, 51, 639661; doi: 10.1016/j.cretres.2015.08.001.

Crusafont, M. \& Villalta, J.F. 1948. Los castores fósiles de España. Boletín del Instituto Geológico y Minero de España, 61, 321-449.

Delclòs, X., Arillo, A., Peñalver, E., Barrón, E., Soriano, C., López del Valle, R., Bernárdez, E., Corral, J.C. \& Ortuño, V.M. 2007. Fossiliferous amber deposits from the Cretaceous (Albian) of Spain. Comptes Rendus Palevol, 6, 135-149; doi: 10.1016/j.crpv.2006.09.003.

Díaz-Berenguer, E., Badiola, A., Moreno-Azanza, M. \& Canudo, J.I. 2018a. First adequately-known quadrupedal sirenian from Eurasia (Eocene, Bay of Biscay, Huesca, northeastern Spain). Scientific Reports, 8, 5127; doi: 10.1038/s41598-018-23355-w.

Díaz-Berenguer, E., Badiola, A., Canudo, J.I. \& Astibia, H. 2018b. El retorno de los mamíferos al medio acuático: sirenios del Eoceno del Golfo de Bizkaia. In: Registro Fósil de los Pirineos Occidentales. Bienes de Interés Paleontológico y Geológico. Proyección Social (eds. Badiola, A., Gómez-Olivencia, A. \& Pereda-Suberbiola, 
X.). Servicio Central de Publicaciones del Gobierno Vasco, Vitoria-Gasteiz, 151-160.

Díaz-Martínez, I., Hernández, J.M., Fernández, S.G., Murelaga, X. \& Pérez-Lorente, F. 2012. Uvaichnites riojana: A new crane-like bird ichnotaxon from the Lower Miocene of La Rioja (Ebro Basin, Spain). Proceedings of the Geologists'Association, 123, 464-470; doi: 10.1016/j. pgeola.2012.02.003.

Díaz-Martínez, I., Suarez-Hernando, O., Martínez-García, B.M., Larrasoaña, J.C. \& Murelaga, X. 2016. First bird footprints from the lower Miocene Lerín Formation, Ebro Basin, Spain. Palaeontologia Electronica, 19, 1-15; doi: $10.26879 / 604$.

Díaz-Martínez, I., Murelaga, X. \& Astibia, H. 2018. Huellas cenozoicas de aves y mamíferos de los Pirineos occidentales. In: Registro Fósil de los Pirineos Occidentales. Bienes de Interés Paleontológico y Geológico. Proyección Social (eds. Badiola, A., GómezOlivencia, A. \& Pereda-Suberbiola, X.). Servicio Central de Publicaciones del Gobierno Vasco, Vitoria-Gasteiz, 161-168.

Domingo, L., Rodríguez-Gómez, G., Libano, I. \& GómezOlivencia, A. 2017. New insights into the Middle Pleistocene paleoecology and paleoenvironment of the Northern Iberian Peninsula (Punta Lucero Quarry site, Biscay): A combined approach using mammalian stable isotope analysis and trophic resource availability modelling. Quaternary Science Reviews, 169, 243-262; doi: 10.1016/j.quascirev.2017.06.008.

Fernández-Martínez, E. 2018. El patrimonio paleontológico en la encrucijada: características, problemas y propuestas de actuación. In: Registro Fósil de los Pirineos Occidentales. Bienes de Interés Paleontológico y Geológico. Proyección Social (eds. Badiola, A., Gómez-Olivencia, A. \& PeredaSuberbiola, X.). Servicio Central de Publicaciones del Gobierno Vasco, Vitoria-Gasteiz, 219-232.

García-Mondéjar, J. \& Pujalte, V. 1983. Origen, karstificación y enterramiento de unos materiales carbonatados albienses (Punta del Castillo, Górliz, Vizcaya). X Congreso Nacional de Sedimentología, Menorca-83, Libro de Resúmenes, 3.9-3.12.

Gaudant, J. 2003. Prolebias euskadensis nov. sp., nouvelle espèce de poissons Cyprinodontidae apodes de l'OligoMiocène d'Izarra (province d'Álava, Espagne). Revista Española de Paleontología, 18, 171-178.

Gobierno Vasco 2014. Estrategia de Geodiversidad de la Comunidad Autónoma del País Vasco 2020. Ihobe, Sociedad Pública de Gestión Ambiental, Departamento de Medio Ambiente y Política Territorial, Gobierno Vasco, Bilbao, 156 p. Available at http://www.euskadi. eus/contenidos/proyecto/geodibertsitatearen_estrategia/ es_def/adjuntos/geodivers_2020.pdf.

Gómez-Olivencia, A., Arceredillo, D., Álvarez-Lao, D.J., Garate, D., San Pedro, Z., Castaños, P. \& Rios-Garaizar, J. 2014. New evidence for the presence of reindeer (Rangifer tarandus) on the Iberian Peninsula in the Pleistocene: an archaeopalaeontological and chronological reassessment. Boreas, 43, 286-308; doi: 10.1111/bor.12037.
Gómez-Olivencia, A., Sala, N., Arceredillo, D., García, N., Martínez-Pillado, V., Rios-Garaizar, J., Garate, D., Solar, G. \& Libano, I. 2015. The Punta Lucero Quarry site (Zierbena, Bizkaia): a window into the Middle Pleistocene in the Northern Iberian Peninsula. Quaternary Science Reviews, 121, 52-74; doi: 10.1016/j.quascirev.2015.05.001.

Larrasoaña, J.C., Murelaga, X., Peña, J.L. \& Sancho, C. 2018. Bardenas Reales de Navarra. Geología. Guía del Visitante. Comunidad de las Bardenas Reales de Navarra, Tudela, $80 \mathrm{pp}$.

López-Horgue, M.A. 2006. Autovía Eibar-Gasteiz. Lutitas con restos fósiles articulados de clupeomorfos del Cretácico Inferior en Apotzaga (Eskoriatza). Arkeoikuska, 2005, 150-153.

López-Horgue, M.A. \& Hernández, J.M. 2003. La cuenca terciaria continental del Diapiro de Murgia: la Formación Izarra (Oligoceno superior-Mioceno inferior, Cuenca Vasco-Cantábrica). Geogaceta, 33, 123-126.

López-Horgue, M.A., Owen, H.G., Rodríguez-Lázaro, J., Orue-Etxebarria, X., Fernández-Mendiola, P.A. \& García-Mondéjar, J. 1999. Late Albian-Early Cenomanian stratigraphic succession near Estella-Lizarra (Navarra, central northern Spain) and its regional and interregional correlation. Cretaceous Research, 20, 369-402; doi: 10.1006/cres.1999.0162.

López-Horgue, M.A., Poyato-Ariza, F.J., Cavin, L. \& Bermúdez-Rochas, D.D. 2014. Cenomanian transgression in the Basque-Cantabrian Basin (northern Spain) and associated faunal replacement. Journal of Iberian Geology, 40, 489-506; doi: 10.5209/rev_JIGE.2014.v40. n3.42819.

López-Horgue, M.A., Bermúdez-Rochas, D.D. \& PoyatoAriza, F.J. 2018. El registro de peces cretácicos de los Pirineos occidentales: medio ambiente y paleobiogeografía. In: Registro Fósil de los Pirineos Occidentales. Bienes de Interés Paleontológico y Geológico. Proyección Social (eds. Badiola, A., Gómez-Olivencia, A. \& PeredaSuberbiola, X.). Servicio Central de Publicaciones del Gobierno Vasco, Vitoria-Gasteiz, 83-98.

Mendia, M., Hilario, A., Apellaniz, E., Aranburu, A., Carracedo, M., Cearreta, A., Eguiluz, L., Gil Crespo, P.P., González, M.J., López-Horgue, M.A., Martínez-Torres, L.M. \& Mugerza, I. 2013. El Inventario de Lugares de Interés Geológico de la Comunidad Autónoma del País Vasco (CAPV). In: Patrimonio Geológico, un Recurso para el Desarrollo (eds. Vegas, J., Salazar, A., DíazMartínez, E. \& Marchán, C.). Cuadernos del Museo Geominero, 15, 457-466.

Monge-Ganuzas, M., Arana, G. \& Mendia, M. 2018. El Inventario de Lugares de Interés Geológico y la Estrategia de Geodiversidad en la Comunidad Autónoma del País Vasco. In: Registro Fósil de los Pirineos Occidentales. Bienes de Interés Paleontológico y Geológico. Proyección Social (eds. Badiola, A., Gómez-Olivencia, A. \& PeredaSuberbiola, X.). Servicio Central de Publicaciones del Gobierno Vasco, Vitoria-Gasteiz, 239-255.

Moratalla, J.J., García-Mondéjar, J., Dos Santos, V.F., Lockley, M.G., Sanz, J.L. \& Jiménez, S. 1994. Sauropod 
trackways from the Lower Cretaceous of Spain. Gaia, 10, 75-83.

Moreno García, J. 2018. La protección del patrimonio paleontológico como parte del patrimonio arqueológico en la Comunidad Autónoma del País Vasco. In: Registro Fósil de los Pirineos Occidentales. Bienes de Interés Paleontológico y Geológico. Proyección Social (eds. Badiola, A., Gómez-Olivencia, A. \& Pereda-Suberbiola, X.). Servicio Central de Publicaciones del Gobierno Vasco, Vitoria-Gasteiz, 233-238.

Murelaga, X., Pereda-Suberbiola, X., Lapparent de Broin, F. de, Rage, J.-C., Duffaud, S., Astibia, H. \& Badiola, A. 2002. Amphibians and reptiles from the Early Miocene of the Bardenas Reales of Navarre (Ebro Basin, Iberian Peninsula). Geobios, 35, 347-365; doi: 10.1016/S00166995(02)00031-1.

Murelaga, X., Astibia, H., Sesé, C., Soria, D. \& PeredaSuberbiola, X. 2004. Mamíferos del Mioceno inferior de las Bardenas Reales de Navarra (Cuenca del Ebro, Península Ibérica). Munibe (Ciencias Naturales - Natur Zientziak), 55, 7-102.

Murelaga, X., Baceta, J.I., Anadón, P., Apraiz, A., Aranburu, A., Martin-Rubio M., Ortega, L.A., Rage, J.C., Tarriño, A., Zuluaga, M.C., Wolf, D. \& Zubeldia, H. 2006. Lower Eocene lacustrine record in Loza (southern BasqueCantabrian Basin): Biostratigraphic and paleoclimatic inferences. In: Climate and Biota of the Early Paleogene 2006 (eds. Caballero, F., Apellaniz, E., Baceta, J.I., Bernaola, G., Orue-Etxebarria, X., Payros, A. \& Pujalte, V.). Volume of Abstracts. Bilbao, p. 88.

Murelaga, X., Astibia, H., Baceta, J.I., Almar, Y., Beamud, B. \& Larrasoaña, J.C. 2007. Fósiles de pisadas de aves en el Oligoceno de Etaio (Navarra, Cuenca del Ebro). Geogaceta, 41, 147-150.

Payros, A., Astibia, H., Cearreta, A., Pereda Suberbiola, X., Murelaga, X. \& Badiola, A. 2000. The Upper Eocene South Pyrenean coastal deposits (Liedena Sandstone, Navarre): Sedimentary facies, benthic foraminifera and avian ichnology. Facies, 42, 107-132; doi: 10.1007/BF02562569.

Payros, A., Pujalte, V., Tosquella, J. \& Orue-Etxebarria, X. 2010. The Eocene storm-dominated foralgal ramp of the western Pyrenees (Urbasa-Andia Formation): An analogue of future shallow-marine carbonate systems? Sedimentary Geology, 228, 184-204; doi: 10.1016/j.sedgeo.2010.04.010.

Pereda-Suberbiola, X. 2018. Dinosaurios y otros vertebrados continentales del Cretácico final de la Región VascoCantábrica: cambios faunísticos previos a la extinción finimesozoica. In: Registro Fósil de los Pirineos Occidentales. Bienes de Interés Paleontológico y Geológico. Proyección Social (eds. Badiola, A., GómezOlivencia, A. \& Pereda-Suberbiola, X.). Servicio Central de Publicaciones del Gobierno Vasco, Vitoria-Gasteiz, 83-98.

Pereda-Suberbiola, X., Corral, J.C., Astibia, H., Badiola, A., Bardet, N., Berreteaga, A., Buffetaut, E., Buscalioni, A.D., Cappetta, H., Cavin, L., Díez Díaz, V., Gheerbrant, E., Murelaga, X., Ortega, F., Perez-García, A., PoyatoAriza, F., Rage, J.C., Sanz, J.L. \& Torices, A. 2015. Late
Cretaceous continental and marine vertebrate assemblages of the Laño Quarry (Basque-Cantabrian Region, Iberian Peninsula): an update. Journal of Iberian Geology, 41, 101-124; doi: 10.5209/rev_JIGE.2015.v41.n1.48658.

Poyato-Ariza, F.J., López-Horgue, M.A. \& García-Garmilla, F. 2000. A new early Cretaceous clupeomorph fish from the Arratia Valley, Basque Country, Spain. Cretaceous Research, 21, 571-585; doi: 10.1006/cres.2000.0212.

Robles, S., Pujalte, V. \& García-Mondéjar, J. 1988. Evolución de los sistemas sedimentarios del margen continental cantábrico durante el Albiense y Cenomaniense, en la transversal del litoral vizcaíno. Revista de la Sociedad Geológica de España, 1, 409-441.

Rodrigo, A., Peñalver, E., López del Valle, R., Barrón, E. \& Delclòs, X. 2018. The Heritage Interest of the Cretaceous Amber Outcrops in the Iberian Peninsula, and their Management and Protection. Geoheritage, 10, 511-523; doi: 10.1007/s12371-018-0292-1.

Ruiz de Arcaute, F. \& San Martín, J. 1967. Conjunto de los fenómenos espeleológicos de Gesaltza, Arrikrutz, Jaturabe y Cueva de los Osos. Munibe, 8, 10-28.

Ruiz de Gaona, M. 1941. Un yacimiento de mamíferos pleistocénicos en Olazagutía (Navarra). Boletín de la Real Sociedad Española de Historia Natural, 39, 155-160.

Ruiz de Gaona, M., Villalta, J.F. \& Crusafont, M. 1946. El yacimiento de mamíferos fósiles de las Yeseras de Monteagudo (Navarra). Notas y Comunicaciones del IGME, 16, 159-185.

Suarez-Hernando, O., Martínez-García, B. \& Murelaga, X. 2018. Paleobiodiversidad de las Bardenas Reales de Navarra. In: Registro Fósil de los Pirineos Occidentales. Bienes de Interés Paleontológico y Geológico. Proyección Social (eds. Badiola, A., Gómez-Olivencia, A. \& PeredaSuberbiola, X.). Servicio Central de Publicaciones del Gobierno Vasco, Vitoria-Gasteiz, 169-177.

Torres, T. (ed.). 2014. La Historia del Oso de las Cavernas: Vida y Muerte de un Animal Desaparecido. Nuevas Aportaciones de la Excavación de la Cueva de Amutxate (Aralar, Navarra). Laboratorio de Estratigrafía Biomolecular, Grupo de Estudios Ambientales, Madrid, 234 p.

Torres, T., Nestares, T., Cobo, R., Ortiz, J.E., Cantero, M.A., Ortiz, J., Vidal, R. \& Prieto, J.O. 2001. Análisis morfológico y métrico de la dentición y metapodios del oso de Deninger (Ursus deningeri Von Reichenau) de la Cueva Sta. Isabel de Ranero. Aminocronología (Valle de Carranza - Bizkaia - País Vasco). Munibe (Ciencias Naturales - Natur Zientziak), 51, 107-141.

Torres, T., Ortiz, J.E., Fernández, E., Arroyo-Pardo, E., Grün, R. \& Pérez-González, A. 2014. Aspartic acid racemization as a dating tool for dentine: A reality. Quaternary Geochronology, 22, 43-56; doi: 10.1016/j. quageo.2014.02.004.

Vegas, J., Delvene, G., Menéndez, S., Rábano, I., GarcíaCortés, A., Díaz-Martínez, E. \& Jiménez, R. 2018. El patrimonio paleontológico en España: una necesidad de consenso sobre su gestión y marco legal. Revista PH, 94, 326-329. 